\title{
ANALISIS TINGKAT KECACATAN PRODUK LEVER ASSY PARKING BRAKE MENGGUNAKAN METODE STATISTICAL QUALITY CONTROL (SQC)
}

\section{Defect Analysis of Lever Assy Parking Brake using Statistical Quality Control $(S Q C)$}

\author{
Rianita Puspa Sari ${ }^{1 *}$, Dewi Puspita ${ }^{1}$ \\ ${ }^{1}$ Program Studi Teknik Industri, Universitas Singaperbangsa Karawang, Jl. H. S. Ronggowaluyo, Telukjambe \\ Timur, Karawang 41361, Indonesia
}

Diterima: 16 Juli 2018 / Disetujui: 13 Agustus 2018

\begin{abstract}
The company always tries to meet customer demands, so it must be able to provide good product quality. Quality control is always carried out by manufacturing companies for the creation of zero defects. Lever Assy Parking Brake is part of the cars spare parts produced by manufacturing company $X$ and must have a zero defect product quality level. The purpose of this study was to determine the level of product defect using the Statistical Quality Control (SQC) method. Data was carried out with process control procedures. This study showed that the product defect rate of Lever Assy Parking Brake with Statistical Quality Control (SQC) method in March 2018 was very large. As seen from the 22 data production processes, 13 production process data (59 percent) were out-of-control but still fell within the specification limit of $9 \pm 0.5 \mathrm{~mm}$. Meanwhile, only 9 data production processes (41 percent) were in control. So there is a need to analyze causes and corrective actions. $R$ control chart shows the process that has been stable or under control has a UCL (Upper Control Limit) value of 0.21, the LCL (Lower Control Limit) value of 0 and a value of $C L$ (central line) of 0.10. Whereas $\bar{x}$ chart shows the control limit with UCL value of 9.39, LCL value is 9.27 and $C L$ value is 9.33 .
\end{abstract}

Keywords: Product quality, production process, $R$ chart, $\bar{x}$ chart, Statistical Quality Control

\begin{abstract}
ABSTRAK
Perusahaan selalu berusaha memenuhi tuntutan pelanggan, sehingga harus mampu memberikan kualitas produk yang baik. Pengendalian kualitas selalu dilakukan oleh perusahaan manufaktur demi terciptanya zero defect. Lever Assy Parking Brake bagian dari sparepart mobil yang diproduksi oleh perusahaan manufaktur $\mathrm{X}$ haruslah memeliki tingkat kualitas produk zero defect. Tujuan penelitian ini, untuk mengetahui tingkat kecacatan produk dengan menggunakan metode Statistical Quality Control (SQC). Pengumpulan Data dilakukan dengan prosedur process control, hasil penelitian menujukkan Tingkat kecacatan produk Lever Assy Parking Brake dengan metode Statistical Quality Control (SQC) pada bulan Maret 2018 menunjukkan bahwa tingkat kecacatan sangat besar terlihat dari 22 data proses produksi terdapat 13 data proses produksi yang berada di luar batas atau sebesar $59 \%$ namun masih termasuk ke dalam batas spesifikasi yaitu $9 \pm 0.5 \mathrm{~mm}$ sedangkan data proses produksi yang berada dalam batas pengendalian sebanyak 9 data proses produksi atau sekitar $41 \%$ sehingga perlu adanya analisa penyebab dan tindakan perbaikan. Peta kendali $\mathrm{R}$ dengan proses telah stabil atau berada dalam pengendalian memiliki nilai UCL (Upper Control Limit) sebesar 0.21, nilai LCL (Lower Control Limit) sebesar 0 dan nilai CL (central line) sebesar 0.10. Sedangkan Peta kendali $\bar{x}$ berada dalam batas kendali dengan nilai UCL sebesar 9.39, nilai LCL sebesar 9.27 dan nilai CL sebesar 9.33.
\end{abstract}

Kata Kunci: Kualitas produk, proses produksi, peta kendali R, peta kendali $\bar{x}$, Statistical Quality Control

*e-mail: rianita.puspasari@ft.unsika.ac.id 


\section{PENDAHULUAN}

Tuntutan pelanggan yang senantiasa berubah, menuntut perusahaan untuk lebih fleksibel dalam memenuhi tuntutan pelanggan yang berhubungan langsung dengan seberapa baiknya kualitas produk yang diterima oleh pelanggan. Hal ini menyebabkan perusahaan harus dapat mempertahankan kualitas produk yang dihasilkan atau bahkan lebih baik (Hatani, 1997). Karakteristik yang harus diperhitungkan dalam mendefinisikan produk yang berkualitas, yaitu pendekatan subyektif yang menekankan pada pandangan terhadap kualitas secara eksternal kesesuaian produk atau jasa yang dihasilkan dengan standar eksternal yang berupa keinginan atau harapan pelanggan atau disebut kekesuaian untuk digunakan pelanggan (Zhang, 2000).

Secara umum pelanggan melihat kualitas suatu produk berdasarkan daya tahan produk, desain produk, dan manfaat atau fungsi dari produk itu sendiri, sehingga perusahaan dapat mengukur kualitas produk yang diproduksi selain secara teknis, juga dapat dilihat dari bagaimana sikap pelanggan terhadap kualitas produk. Semakin positif respon pelanggan maka semakin tinggi kualitas suatu produk. Namun tidak menutup kemungkinan bahwa secara tidak langsung perusahaan akan menciptakan produk yang tidak sesuai atau yang disebut produk cacat (defect). Maka dari itu, dalam suatu perusahaan dibutuhkan komitmen manajemen yang tinggi untuk memberikan dan menyalurkan nilai pelanggan serta pengendalian pada kualitas demi tercipta zero defect atau kesalahan mendekati nol (Hartini, 2012).

Perusahaan manufaktur yang memproduksi sparepart mobil yang disebut Lever Assy Parking Brake dan Cover Parking Brake untuk beberapa perusahaan besar otomotif sebagai pelanggannya, haruslah memiliki tujuan zero defect terhadap hasil produksinya. Namun sejak beridirinya perusahaan tahun 2015 hingga bulan Februari 2018 perusahaan belum mampu mencapai zero defect walaupun setiap tahunnya mengalami penurunan tingkat kecacatan. Berdasarkan laporan bulanan yang dituangkan dalam form Monthly Report bahwa pada Bulan Maret 2017 memiliki tingkat kecacatan $0.017 \%$ dari total produksi 98.775 unit, sedangkan untuk bulan Maret 2018 memiliki tingkat kecacatan $0.008 \%$ dari total produksi 99.935 unit. Dari total tingkat kecacatan, produk Lever Assy Parking Brake memberikan tingkat kecacatan sebesar $0.005 \%$. Meskipun tingkat kecacatan mendekati nol akan tetapi perusahaan tetap memerlukan suatu aktifitas dalam menciptakan kualitas yang sesuai standar. Salah satu aktifitas dalam menciptakan kualitas yang sesuai standar adalah menerapkan sistem pengendalian kualitas yang tepat, mempunyai tujuan dan tahapan yang jelas serta memberikan inovasi dalam melakukan pencegahan dan penyelesaian masalah-masalah yang dihadapi untuk mengurangi tingkat kecacatan bahkan menghasilkan zero defect pada periode berikutnya (Panji, 2015).

Pengendalian kualitas dapat dilakukan dengan berbagai metode seperti Quality Control (QC) tradisional, Quality Function Deployment (QFD), Quality Control Circle (QCC), Statistical Qualitty Control (SQC) dan lain-lain (Assauri, 2008). Metode SQC telah banyak digunakan dalam beberapa penelitian untuk memperbaiki kualitas (Meri, Irsan dan Wijaya, 2017).

Berdasarkan hal tersebut, diperlukannya suatu operational procedure pengendalian kualitas produk jadi pada departemen quality assurance, selain itu penelitian ini ingin mengetahui tingkat kecacatan produk Lever Assy Parking Brake menggunakan metode Statistical Quality Control (SQC).

\section{METODOLOGI}

Dalam Statistical Quality Control (SQC) terdapat dua metode yang dapat digunakan dalam pengendalian kualitas secara statistik, yaitu (Assauri, 2008): (1) Acceptance Sampling berupa pengambilan satu sampel atau lebih secara acak dari suatu barang, memeriksa setiap sampel barang tersebut dan memutuskan, apakah menerima atau menolak keseluruhan barang. (2) Process Control berupa pemeriksaan produk atau jasa ketika barang tersebut masih sedang diproduksi (WIP/ Work In Process). Sampel berkala diambil dari output proses produksi.

Pada penelitian ini, Pemeriksaan produk yang dilakukan menerapkan metode process controll yang dapat dilihat pada Gambar 1, dimana sampel secara berkala diambil dari output proses produksi yang kemudian dicatat dalam Production Line Self Check Sheet (PLSCS). Adapun point check dalam penelitian ini berupa diameter produk dengan spesifikasi 9 $\pm 0.5 \mathrm{~mm}$ yang merupakan salah satu dari 14 point check lainnya. 


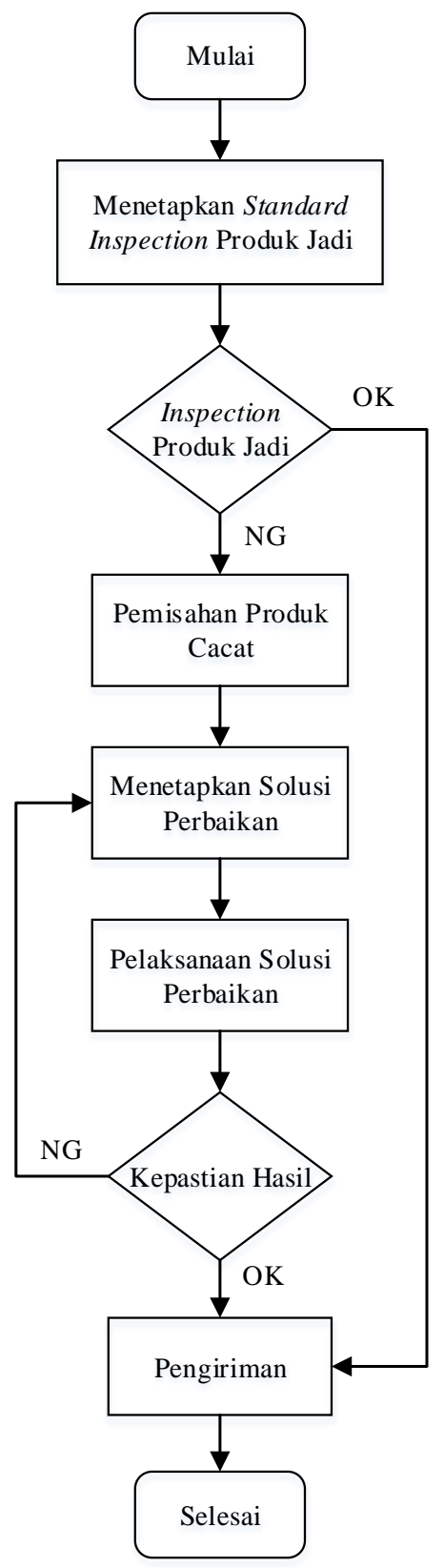

Gambar 1. Prosedur Process Control

\section{HASIL DAN PEMBAHASAN}

Pengumpulan data, dilakukan dengan pengamatan data pemeriksaan produk Lever Assy Parking Brake. Dari hasil pengumpulan data, dilakukan analisis tingkat kecacatan dengan menggunakan pengendalian kualitas secara statistik atau Statistical Quality Control (SQC) dengan menggunakan peta kendali variabel karena dapat dilihat berdasarkan data pemeriksaan bahwa point check berupa diameter dengan spesifikasi $9 \pm 0.5 \mathrm{~mm}$. Maka analisis tingkat kecacatan dapat dilakukan dengan peta kendali rata-rata $(\bar{x}$ chart $)$ dan peta kendali rentang ( $\mathrm{R}$ chart) dengan data dalam satuan milimeter (mm).

Hasil pengolahan data Tabel 1 untuk peta kendali R produk Lever Assy Parking Brake yang ditunjukkan pada Gambar 2 terlihat bahwa beberapa data produk dalam suatu proses produksi berada di luar batas-batas pengendalian yaitu data pada nomor 21 dan nomor 22. Adapun nilai dari kepresisian produk dalam proses produksi nomor 21 sebesar $0.35 \mathrm{~mm}$ dan nomor 22 sebesar $0.36 \mathrm{~mm}$, sedangkan hasil pengolahan data menunjukkan bahwa peta kendali R memiliki nilai UCL (Upper Control Limit) sebesar $0.26 \mathrm{~mm}$, nilai LCL (Lower Control Limit) sebesar $0 \mathrm{~mm}$ dan nilai CL (central line) sebesar $0.12 \mathrm{~mm}$ yang berarti proses pada data nomor 21 dan 22 berada di luar batas UCL atau berada di luar batas atas pengendalian statistik. Dengan adanya data yang keluar dari batas pengendalian maka terdapat hasil produksi yang tidak presisi dengan spesifikasi produk yang telah ditentukan. Hal ini menunjukkan bahwa persyaratan mutunya kurang baik sehingga hasil proses produksi pada data proses nomor 21 dan nomor 22 dikeluarkan untuk diadakan perbaikan.

Berdasarkan

langkah-langkah perhitungan peta kendali $\mathrm{R}$, apabila terdapat data proses yang keluar dari batas-batas pengendalian maka lakukan kembali perhitungan dengan tidak mengikutsertakan data yang berada diluar batas pengendalian dan pengulangan perhitungan berhenti setelah data berada dalam batas pengendalian. Setelah dilakukan perhitungan kembali dengan tidak mengikutsertakan 2 data proses yang berada diluar batas pengendalian diperoleh hasil pengolahan data pada Gambar 3 yang menunjukkan bahwa data proses untuk peta kendali $\mathrm{R}$ berada dalam batas kendali yang artinya proses telah stabil dan berada dalam pengendalian dengan memiliki nilai UCL (Upper Control Limit) sebesar 0.21, nilai LCL (Lower Control Limit) sebesar 0 dan nilai CL (central line) sebesar 0.10 .

Dengan terkendalinya data proses produksi produk Lever Assy Parking Brake, selanjutnya dapat dilakukan perhitungan untuk membuat peta kendali rata-rata ( $\bar{x}$ chart). Peta kendali rata-rata ( $\bar{x}$ chart) merupakan peta kendali yang menunjukkan keakuratan produk dalam suatu proses produksi. Gambar 4 menunjukkan hasil perhitungan peta kendali $\bar{x}$ 
dengan jumlah 20 data proses dengan nilai UCL (Upper Control Limit) sebesar $9.37 \mathrm{~mm}$, nilai LCL (Lower Control Limit) sebesar $9.26 \mathrm{~mm}$, dan nilai CL (Central Line) sebesar $9.31 \mathrm{~mm}$. Dari Tabel 2 dapat dilihat bahwa UCL (Upper Control Limit) dan nilai LCL (Lower Control Limit) berada dalam batas spesifikasi, hal ini menunjukkan bahwa persyaratan mutu produk Lever Assy Parking Brake tergolong memenuhi spesifikasi yang telah ditentukan perusahaan sesuai permintaan pelanggan.

Namun pada Gambar 4 dapat dilihat bahwa terdapat 11 (sebelas) data proses berada di luar batas pengendalian UCL (Upper Control Limit) maupun LCL (Lower Control Limit) yaitu pada data proses produksi nomor 1, 2, 4,5,9,10, 13, 14, 15, 18 dan 19. Hal ini menunjukkan keakuratan proses tak terkendali atau proses berada diluar batas pengendalian statistik artinya persyaratan mutunya kurang baik dengan keakuratan beberapa produk yang dihasilkan tidak sama dengan data yang sebenarnya. Adapun untuk nilai 11 data proses yang berada di luar batas UCL dan LCL berturut-turut adalah 9.16, 9.16, 9.17, 9.18, 9.41, 9.44, 9.46, 9.46, $9.40,9.25$ dan 9.23. Maka dari itu perlu adanya analisis penyebab tidak terkendalinya suatu proses produksi.

Sebelum melakukan analisis penyebab tidak terkendalinya 11 proses produksi produk Lever Assy Parking Brake, seperti pada langkahlangkah menghitung peta kendali $\mathrm{R}$, apabila terdapat data proses yang keluar dari batas-batas pengendalian maka lakukan kembali perhitungan dengan tidak mengikutsertakan data yang berada diluar batas pengendalian dan pengulangan perhitungan berhenti setelah data berada dalam batas pengendalian. Hal ini juga berlaku pada langkah-langkah mengitung peta kendali $\bar{x}$.

Perhitungan kembali dilakukan tanpa mengikutsertakan 11 data proses yang berada di luar batas pengendalian bertujuan untuk mengetahui data proses yang tersisa yaitu 9 (sembilan) data berada dalam pengendalian statistik atau tidak. Hasil pengolahan data menunjukkan bahwa nilai UCL (Upper Control Limit) sebesar $9.39 \mathrm{~mm}$, nilai LCL (Lower Control Limit) sebesar $9.27 \mathrm{~mm}$ dan nilai CL (Central Line) sebesar $9.33 \mathrm{~mm}$ yang ditunjukkan pada Gambar 5 bahwa data proses produksi telah berada dalam batas kendali karena tidak ada data yang keluar dari batas pengendalian dan berarti proses sudah kembali stabil. Adapun batas-batas pengedalian untuk hasil pengolahan data revisi untuk produk Lever Assy Parking Brake ditunjukkan pada Tabel 3, menunjukkan bahwa persyaratan mutu produk Lever Assy Parking Brake tergolong memenuhi spesifikasi yang telah ditentukan perusahaan sesuai permintaan pelanggan.

Dari keseluruhan proses terlihat bahwa terdapat 9 dari 22 data proses produksi atau $41 \%$ yang berada dalam batas pengendalian statistik dengan tingkat kecacatan sekitar 59\% dari total 22 data proses produksi namun masih termasuk ke dalam batas spesifikasi yaitu $9 \pm 0.5 \mathrm{~mm}$ yang artinya perlu adanya analisa penyebab untuk melakukan perbaikan. Analisa penyebab difokuskan pada beberapa data proses yang keluar dari batas-batas pengendalian hasil perhitungan peta kendali $\bar{x}$. Terdapat beberapa faktor yang menyebabkan sebagian besar proses produksi berada diluar batas kendali. Adapun analisis faktor penyebab proses tidak terkendali yang menyebabkan tingkat kecacatan 59\% ditampilkan pada analisa diagram sebab akibat yang ditunjukkan pada Gambar 6 dan diagram pareto pada Gambar 7.

Tabel 1. Nilai Rentang (R) dan Nilai rata-rata $(\bar{x})$ setiap pemeriksaan produk

\begin{tabular}{|c|c|c|c|c|c|c|c|}
\hline \multirow{2}{*}{$m$} & \multicolumn{5}{|c|}{ Pemeriksaan (n) } & \multirow{2}{*}{$\mathbf{R}$} & \multirow{2}{*}{$\bar{X}$} \\
\hline & 1 & 2 & 3 & 4 & 5 & & \\
\hline 1 & 9,16 & 9,14 & 9,17 & 9,15 & 9,18 & 0,04 & 9,16 \\
\hline 2 & 9,20 & 9,16 & 9,15 & 9,13 & 9,15 & 0,07 & 9,16 \\
\hline 3 & 9,28 & 9,30 & 9,31 & 9,31 & 9,31 & 0,03 & 9,30 \\
\hline 4 & 9,32 & 9,31 & 9,25 & 9,29 & 9,34 & 0,09 & 9,30 \\
\hline 5 & 9,16 & 9,17 & 9,13 & 9,17 & 9,23 & 0,10 & 9,17 \\
\hline 6 & 9,19 & 9,18 & 9,12 & 9,16 & 9,24 & 0,12 & 9,18 \\
\hline 7 & 9,28 & 9,29 & 9,32 & 9,35 & 9,35 & 0,07 & 9,32 \\
\hline 8 & 9,32 & 9,39 & 9,33 & 9,36 & 9,45 & 0,13 & 9,37 \\
\hline 9 & 9,28 & 9,41 & 9,41 & 9,48 & 9,48 & 0,20 & 9,41 \\
\hline 10 & 9,38 & 9,43 & 9,46 & 9,41 & 9,50 & 0,12 & 9,44 \\
\hline 11 & 9,30 & 9,42 & 9,29 & 9,41 & 9,45 & 0,16 & 9,37 \\
\hline 12 & 9,36 & 9,30 & 9,36 & 9,37 & 9,37 & 0,07 & 9,35 \\
\hline 13 & 9,42 & 9,45 & 9,45 & 9,48 & 9,48 & 0,06 & 9,46 \\
\hline 14 & 9,48 & 9,48 & 9,44 & 9,45 & 9,44 & 0,04 & 9,46 \\
\hline 15 & 9,39 & 9,43 & 9,40 & 9,40 & 9,38 & 0,05 & 9,40 \\
\hline 16 & 9,41 & 9,38 & 9,35 & 9,38 & 9,25 & 0,16 & 9,35 \\
\hline 17 & 9,30 & 9,30 & 9,28 & 9,25 & 9,32 & 0,07 & 9,29 \\
\hline 18 & 9,35 & 9,27 & 9,19 & 9,20 & 9,25 & 0,16 & 9,25 \\
\hline 19 & 9,24 & 9,19 & 9,22 & 9,21 & 9,29 & 0,10 & 9,23 \\
\hline 20 & 9,36 & 9,29 & 9,21 & 9,40 & 9,35 & 0,19 & 9,32 \\
\hline 21 & 9,26 & 9,61 & 9,51 & 9,41 & 9,37 & 0,35 & \\
\hline \multirow[t]{2}{*}{22} & 9,76 & 9,44 & 9,45 & 9,40 & 9,40 & 0,36 & \\
\hline & & & & & $\sum$ & 2,74 & 186,30 \\
\hline
\end{tabular}


Tabel 2. Batas-Batas Pengendalian Produk Lever Assy Parking Brake

\begin{tabular}{lcc}
\hline \multicolumn{1}{c}{$\begin{array}{c}\text { Batas } \\
\text { Pengendalian }\end{array}$} & $\begin{array}{c}\text { Hasil Analisis } \\
\text { (Maret 2018) }\end{array}$ & $\begin{array}{c}\text { Batas } \\
\text { Spesifikasi }\end{array}$ \\
\cline { 1 - 2 } $\begin{array}{l}\text { CL (Center } \\
\text { Line) }\end{array}$ & $9.31 \mathrm{~mm}$ & \\
\cline { 1 - 2 } $\begin{array}{l}\text { UCL (Upper } \\
\text { Center Line) }\end{array}$ & $9.37 \mathrm{~mm}$ & $\begin{array}{c}9 \pm 0.5 \\
\mathrm{~mm}\end{array}$ \\
\cline { 1 - 2 } $\begin{array}{l}\text { LCL (Lower } \\
\text { Center Line) }\end{array}$ & $9.26 \mathrm{~mm}$ & \\
\hline
\end{tabular}

Tabel 3. Batas-Batas Pengendalian Revisi Produk Lever Assy Parking Brake

\begin{tabular}{lcc}
\hline \multicolumn{1}{c}{$\begin{array}{c}\text { Batas } \\
\text { Pengendalian }\end{array}$} & $\begin{array}{c}\text { Hasil Analisis } \\
\text { (Maret 2018) }\end{array}$ & $\begin{array}{c}\text { Batas } \\
\text { Spesifikasi }\end{array}$ \\
$\begin{array}{lll}\text { CL (Center } \\
\text { Line) }\end{array}$ & $9.33 \mathrm{~mm}$ & \\
\cline { 1 - 2 } $\begin{array}{l}\text { UCL (Upper } \\
\text { Center Line) }\end{array}$ & $9.39 \mathrm{~mm}$ & $\begin{array}{c}9 \pm 0.5 \\
\mathrm{~mm}\end{array}$ \\
\cline { 1 - 2 } $\begin{array}{l}\text { LCL (Lower } \\
\text { Center Line) }\end{array}$ & $9.27 \mathrm{~mm}$ & \\
\cline { 1 - 2 } & & \\
\hline
\end{tabular}

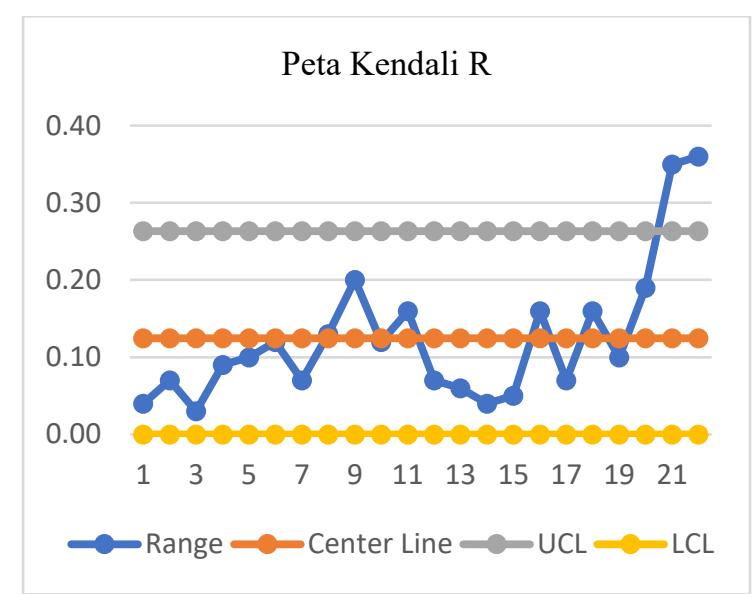

Gambar 2. Peta Kendali R Sumber: Pengolahan Data (2018)

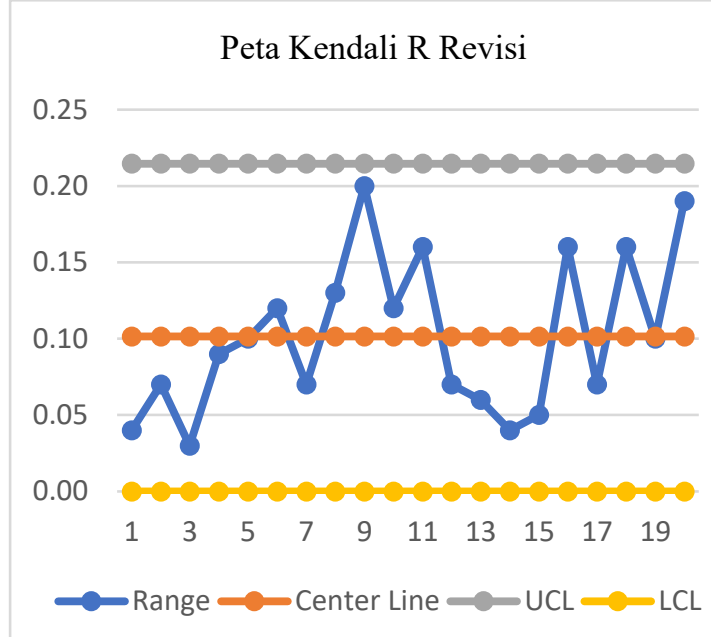

Gambar 3. Peta Kendali R Revisi Sumber: Pengolahan Data (2018)

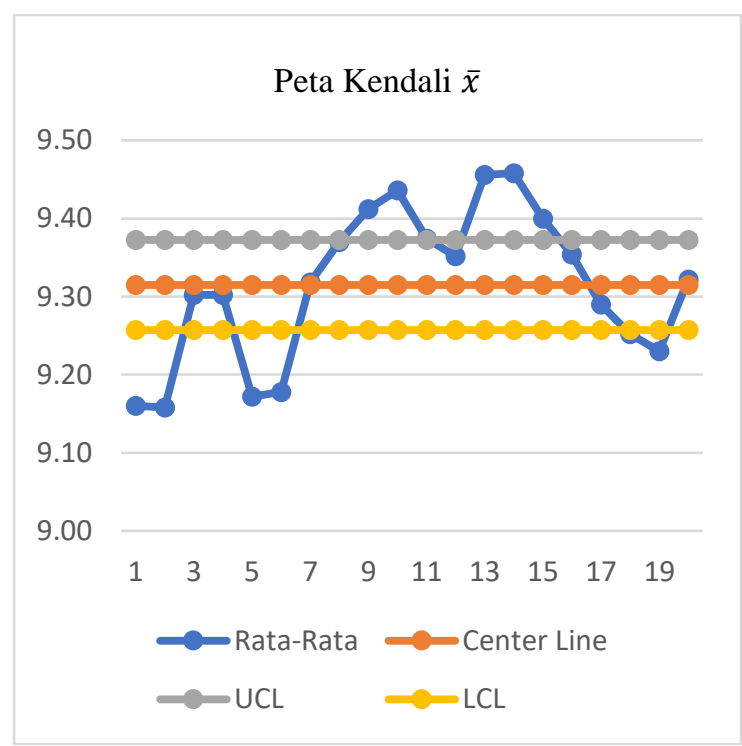

Gambar 4. Peta Kendali $\bar{x}$

Sumber: Pengolahan Data (2018)

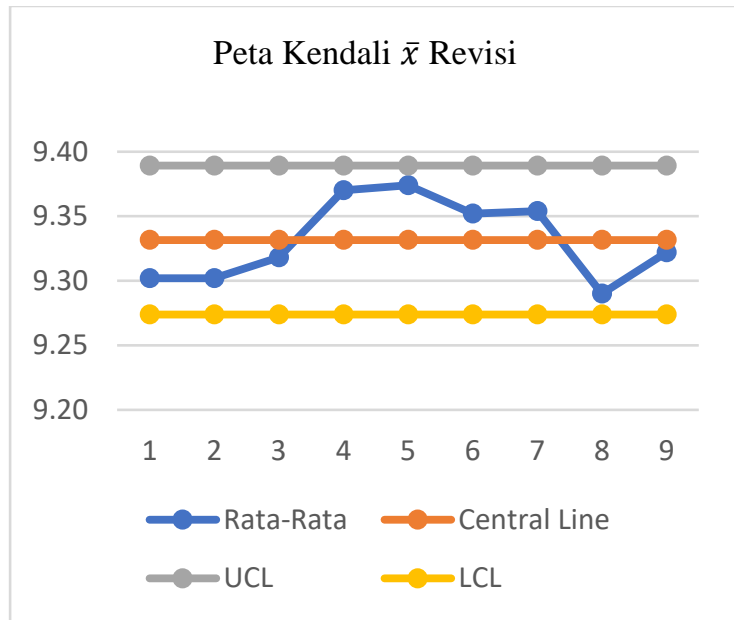

Gambar 4. Peta Kendali $\bar{x}$ Revisi

Sumber: Pengolahan Data (2018) 


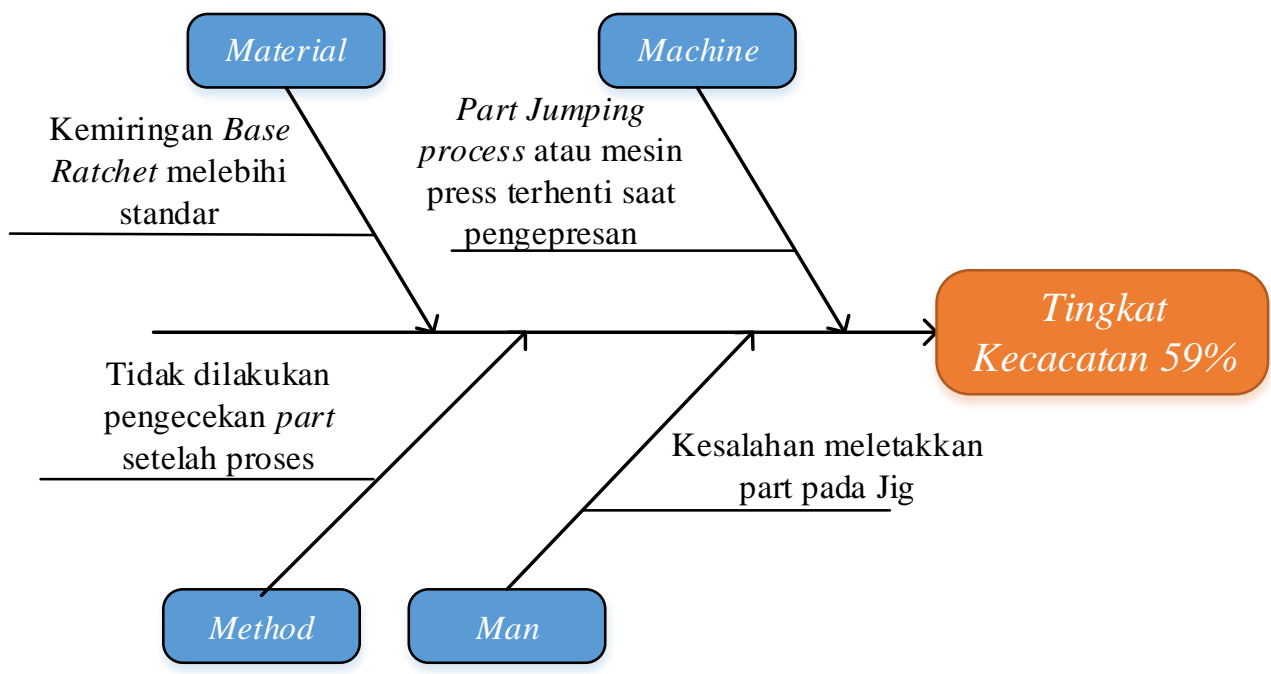

Gambar 6. Analisa Penyebab Tidak Terkendalinya Proses Produksi

Sumber: Pengolahan Data (2018)

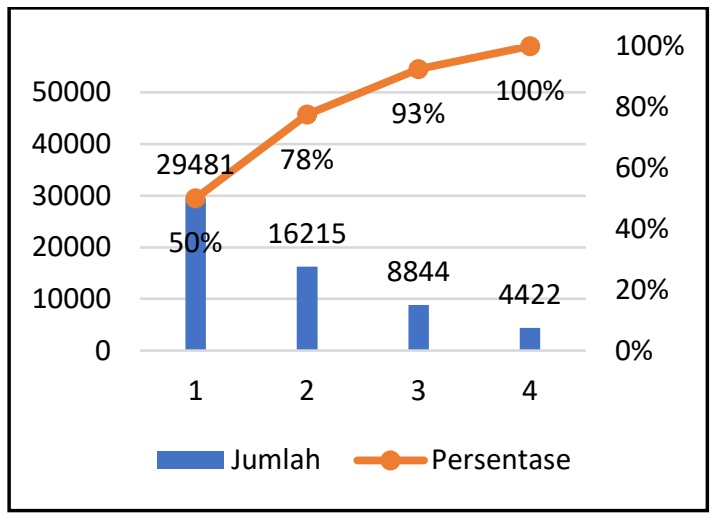

Gambar 7. Diagram Pareto

Keterangan:

1 : Kemiringan Base Rachet melebihi standar

2 : Tidak dilakukan pengecekan setelah proses

3 : Part Jumping Process atau mesin press terhenti saat pengepresan

4 : Kesalahan meletakkan part pada jig

\section{SIMPULAN}

Proses pemeriksaan kualitas produk Lever Assy Parking Brake saat proses produksi dengan menggunakan metode Statistical Quality Control (SQC) bahwa dari 22 data proses produksi terdapat 13 data proses produksi yang berada di luar batas pengendalian yang dihasilkan pada bulan Maret 2018 sebesar 59\% sedangkan data proses produksi yang berada dalam batas pengendalian sebanyak 9 data proses produksi atau sebesar $41 \%$. Akan tetapi 13 data proses produksi yang berada di luar batas pengendalian memiliki nilai rata-rata yang masuk ke dalam spesifikasi produk yang telah ditetapkan yaitu $9 \pm 0.5 \mathrm{~mm}$. Sehingga dapat disimpulkan bahwa point check diameter produk Lever Assy Parking Brake tidak menghasilkan produk di luar batas spesifikasi yang telah ditetapkan. Namun besarnya tingkat proses produksi di luar batas pengendalian ini menunjukkan bahwa perlu adanya analisis penyebab dan tindakan perbaikan untuk mencegah terjadinya produk NG. Peta kendali $\mathrm{R}$ dengan proses telah stabil atau berada dalam pengendalian memiliki nilai UCL (Upper Control Limit) sebesar 0.21, nilai LCL (Lower Control Limit) sebesar 0 dan nilai CL (central line) sebesar 0.10. Sedangkan Peta $\bar{x}$ berada dalam batas kendali dengan nilai UCL sebesar 9.39, nilai LCL sebesar 9.27 dan nilai CL sebesar 9.33 .

Faktor penyebab tingkat kecacatan mencapai $59 \%$ atau sebagian data proses berada di luar batas pengendalian karena ditemukan salah satu material atau part Lever Assy Parking Brake yaitu base ratchet yang memiliki kemiringan melebihi standar yang telah ditetapkan sehingga menyebabkan pemasangan part lainnya tidak presisi dengan ukuran yang telah ditetapkan. Kurangnya ketelitian operator dalam proses peletakkan part pada jig yang menyebabkan part yang diproses tidak sesuai dengan batas spesifikasi. Selain itu terdapat method/metode yang tidak dilakukan sesuai dengan Standard Operational Procedure (SOP) pada saat setelah proses yaitu tidak melakukan metode 
pengecekaan pada part. Sedangkan pada proses produksi mesin press yang digunakan mengalami ganguan karena pada saat proses produksi berlangsung mesin press berhenti bekerja yang menyebabkan hasil pengepresan yang tidak sempurna.

\section{DAFTAR PUSTAKA}

Assauri, S. (2008) Manajemen Produksi dan Operasi. Jakarta: Fakultas Ekonomi Universitas Indonesia.

Hartini, S. (2012) "Peran inovasi: pengembangan kualitas produk dan kinerja bisnis," Jurnal Manajemen dan Kewirausahaan, 14(1), hal. 8288. doi: 10.9744/jmk.14.1.83-90.

Hatani, L. (1997) "Manajemen pengendalian mutu produksi roti melalui pendekatan Statistical Quality Control (SQC)," Jurnal Ekonomi dan Manajemen Unhalu.
Meri, M., Irsan dan Wijaya, H. (2017) "Analisis pengendalian kualitas pada produk SMS (Sumber Minuman Sehat) dengan metode Statistical Process Control (SPC) studi kasus pada PT. Agrimitra Utama Persada Padang," Jurnal Teknologi, 7(1), hal. 119-126.

Panji, D. A. (2015) Analisis pelaksanaan pengendalian kualitas pada proses produksi sepatu di industri Maxil Shoes Cibaduyut Bandung. Universitas Widyatama.

Zhang, Z. (2000) "Developing a model of quality management methods and evaluating their effects on business performance," Total Quality Management, 11(1), hal. 129-137. doi: 10.1080/0954412007071. 